\title{
РЕЦЕНЗИИ
}

\section{ЄМЕЛЬЯНЕНКО Г. Д., РАЙДА К. Ю., ШЕВЧЕНКО С. Л. ЦІННОСТІ ТА ПОСТЕКЗИСТЕНЦІАЛІСТСЬКЕ МИСЛЕННЯ. - К.-П.-С.: ВИД. ПАРАПАН, 2012. - 150 C. ISBN 978-966-2564-04-4}

\author{
І. В. Васильєва \\ доктор філософських наук, професор, завідувач кафедри філософії, біоетики та \\ історії медицини, Національний медичний університет імені О. О. Богомольця \\ ivafilos1403@gmail.com \\ ORCID 0000-0003-3772-5358
}

DOI: https://doi.org/10.34017/1313-9703-2021-1(17)-2(18)-137-140

В умовах ціннісних дезорієнтацій та нігілізму, дегуманізації людини і суспільства, морального та релігійного хаосу, а також переосмислення ролі і місця християнства у формуванні ціннісних та духовних засад, ідентичності західного світу, актуалізується і потреба перевитлумачення світоглядних настанов класичного екзистенціалізму, зокрема, в контексті реалізації "справжньої самості" та пошуку відповіді на запитання: які цінності надалі об'єднуватимуть людей.

Рецензований текст відтворює одну чи не з найперших спроб систематичного дослідження у вітчизняному історико-фрілософському дискурсі феномену загальнолюдських цінностей в таких культурологічних синтезах постекзистенціалістського мислення як екзистенціальна аксіологія, екзистенціальна психологія та екзистенціальна теологія. "Кожен з таких синтезів за своєю сутністю, - як наголошується в передмові до книги, - $є$ типовим прикладом сучасного модернізованого фрілософсько-гуманітарного мислення, яке функціонує у новому інваріанті абсолютно незвичному і відмінному від традиційно відомої його форми" (с. 7). Термін "постекзистенціалістське мислення" автори вживають для підкреслення специфіки і унікальності процесів розвитку філософфії класичного екзистенціалізму в сучасному світі, які $€$ відмінними від понять "постекзистенціалізм" і не вкладаються в сучасну парадигму постмодерну, виступаючи альтернативою постмодерністському мисленню. У ситуації незаповненості культурно-історичного континууму, діалогу культурно-історичних архетипів і смислів, ціннісної та духовної "пустоти" в добу глобаліації "екзистенціальний зміст фрілософії класичного екзистенціалізму та постекзистенціалістського мислення $€$ надзвичайно вагомим як для кожного конкретного індивіда у практиці його духовного самоздійснення та самоактуалізації, так і для гуманітарної науки загалом, оскільки саме цей аспект екзистенціалістської спадщини спрямовує філософію та гуманітарне мислення на новий синтез, на об'єднання з правдивістю, вірогідністю і справедливістю їхніх істин" (с. 16).

Рецензована монографрія своєрідно продовжує відомі дослідження професора К. Ю. Райди, присвячені процесам трансформації класичного екзистенціалізму в систему культурологічних постекзистенціалістських синтезів, зокрема, таких як "Історикофілософрське дослідження постекзистенціалістського мислення" (1998), "Екзистенціальна філософфія. Традиція і перспективи” (2009), з одного боку, стверджуючи і їх правомірність, і їх актуальність, а з іншого, презентуючи та розширюючи виклад змісту концепцій екзистенціальної аксіології, екзистенціальної психології та екзистенціальної теології як феноменів постекзистенціалістського мислення. 
Поглиблене знайомство з текстом монографії залишає позитивне враження оригінальністю постановки дослідницької проблеми, специфікою авторського підходу до іï вирішення та новизною отриманих результатів. Автори рецензованого тексту уперше у вітчизняному історико-фрілософському дискурсі представляють невідомі, або ж раніше заперечувані аспекти трансформації ціннісного сприйняття глобалізованої реальності, аксіологічного мислення Л. В. Баєвої, психологічного мислення Р. Мея, К. Роджерса, А. Маслоу, теологічного мислення П. Тілліха, К. Ранера, Дж. Маккуоррі. Авторська позиція про важливість екзистенціальних вимірів розуміння цінностей взагалі й загальнолюдських цінностей зокрема цілком справедливо обґрунтовується тим, що "раціоналістична культура є лише частиною підстави для формування, інтерпретації та розуміння соціально, і індивідуально значущих цілей та цінностей. Надзвичайно важливу функцію у цих процесах мають і переконання людини, і її психоемоційне налаштування, і її духовний світ, і її світоглядні принципи. Те чи інше трактування цінностей залежить й від загальної філософрсько-світоглядної концепції, з позиції якої інтерпретуються наявні події реальності" (с. 24). В ракурсі інтеграції та глобалізації світу ціннісна проблематика, як випливає з монографії, проявляє себе в кризі раціоналістичного мислення, яке репрезентують, насамперед, “науки про природу”. Але вони значно поступаються "наукам про дух", в яких "нехтування" значущістю буття окремого індивіда - неприпустиме.

Переосмислення та детальний аналіз поглядів Л. В. Баєвої, зокрема її праці “Ціннісні засади індивідуального буття: досвід екзистенціальної аксіології” (2003), дозволяє авторам рецензованої монографії констатувати: “... наукова фрілософфія не приймала у якості провідних аксіологічні проблеми внаслідок їхньої залежності від світу суб'єктивності, світу мінливого і недостовірного з позиції класичної логіки та гносеології" (с. 49), а тому “оцінювання, якщо мати на увазі "відтворення" та функціонування внутрішнього світу індивіда, пов'язане, у першу чергу, з відтворенням одиничного та конкретного, яке у своїй індивідуальній конституалізації в реальному житті не завжди співпадає з загальноприйнятним, і через те істинним. Тому в аксіології повинен бути інший “критерій об'єктивності" істини, особливо, якщо йдеться про істини екзистенційні, про істини існування. Цей критерій повинен містити "поправки" і на суб'єктивність переживання (оцінювання), і на життєво-практичний досвід "теоретизуючого" (оцінюючого) суб'єкта. 3 огляду на це, безумовну доцільність екзистенціальна аксіологія повинна мати у сфрері спостережень над процесами духовного життя та сфері фрормування світогляду різноманітних психологічних типів особистості, оскільки певні особливості психіки, ..., суттєво впливають не тільки на духовне життя людей, але й на процеси ціннісного сприйняття ними світу, на процеси формування їхніх цінностей, становлення їхнього світогляду" (с. 60).

При розгляді проблеми смислів та цінностей в екзистенціальній психології автори монографії пропонують відрізняти екзистенціальну психологію (ії̈ американський варіант) як феномен постекзистенціалістськогоо мислення, яка започатковувалася завдяки методологічним та концептуальним інноваціям, від західно-європейського варіанту екзистенціального аналізу та екзистенціальної психотерапії. Доведено, що традиція креативної трансформації класично-екзистенціалістських ідей започаткована була саме в американській версії екзистенціальної психології, зокрема це стосується ії "головних, концептуальних понять і позицій: цілепокладання, цінностей, природної сутності людської істоти, специфіки функціонування її психоемоційної сфери, мотиваційної діяльності, проблем ідентичності та самоідентифікації, само і смисловираження, самоактуалізації, творчої активності тощо" (с. 79). Водночас скрупульозний аналіз тотожностей та відмінностей американської та західно-європейської екзистенціальної психології дозволяє зробити й інший, не менш важливий висновок: "спираючись на погляди С. Кіркегора, К. Ясперса, Ж.-П. 
Сартра, М. Гайдеггера, М. Мерло-Понті, П. Тілліха, і своїх попередників - Л. Бінсвангера, М. Босса, В. Франкла", - Р. Мей, А. Маслоу та К. Роджерс "створили підгрунтя для цього вчення на американському континенті, стверджуючи необхідність перегляду світоглядних позицій сучасної людини за умов екзистенційної кризи, порушень ідентичності та інших негативних наслідків глобалізації" (с. 93). Як бачимо авторам вдалося розкрити особливості амбівалентності процесу формування екзистенціальної психології, показавши специфіку позитивної трансформації класичного екзистенціалістського методологічного інструментарію, методологічних та методичних прийомів психологічної теорії та психотерапевтичної практики, що дозволяє дослідникам стверджувати про створення умов для розвитку екзистенціальної психології в постекзистенціалістському напрямку.

Роль екзистенціальної теології в добу переоцінки цінностей, "краху дискусу Ісуса Христа" автори висвітлюють на прикладі інноваційних аспектів творчості П. Тілліха, аналізуючи специфіку поєднання ним теології та екзистенціалізму в контексті низки співвідношень його філософії: теологія - філософрія (екзистенціалізм), цінності - смисл, гуманізм - людяність, моралізм - моральність, віра - любов, одкровення - свобода. Автори монографії слушно підкреслюють, що “думка П. Тілліха неначе перетинає кордони фрілософії, теології і психології", а "його екзистенціальна теологія прагне співвіднести між собою одкровення і історичну ситуацію (“кайрос"), християнську віру і світську культуру XX ст." У рецензованій монограсрії здійснюється ретельний аналіз переосмислених Тілліхом головних понять християнської традиції, де "Бог” стає "основою буття", "віра" - "граничною захопленістю", "гріх" - "відчуженням від буття", “благодать" - "прийняттям", а центральний для Реформації принцип "виправдання вірою" трансформується у "виправдання сумнівом"”' (с. 96). Докладний аналіз образної теологічної символіки П. Тілліха ("мужність бути", "нове буття", "кайрос") дозволяє авторам праці узагальнити надзвичайно важливий висновок тілліхової "систематичної теології" "мораль і насправді повинна бути не тільки “живою”, екзистенціальною, вона повинна ще бути "освячена духовністю"' (с. 108-109).

Вплив філософії екзистенціалізму на католицьку теологію автори монографії прослідковують в трансцендентальному томізмі Карла Ранера, зокрема у розвинутій ним екзистенціальній етиці та концепції "анонімного християнства". І цілком мають рацію, коли розглядають К. Ранера, як проголошувача амбітної заповіді: "католицизм повинен намагатися так само наздогнати сучасність, як секулярний світ рухається до чогось іншого, такого невловимого та невідомого, що його називають “пост-сучасністю"' (с. 121), яка засвідчує унікальну претензійність ранерівської теології на життя в майбутньому, адже наполегливо обґрунтовує тезу про те, що слово одкровення повинне знайти корелят в душі слухача.

Виділення та аналіз екзистенціалістських ідей в екзистенціальній теології Дж. Маккуоррі свідчить і про спроби авторського колективу показати евристичну значущість методологічного та ідейного інструментарію філософрії класичного екзистенціалізму та екзистенціалістських постулатів не лише для розвитку сучасного постекзистенціалістського мислення в теології, а й для оберненого шляху до раціонального витлумачення змісту християнської віри та положень Біблії, спроби "виразити зміст цієї віри найбільш зрозумілою і когерентною, доступною мовою” (с. 124). Як доводять автори, Дж. Маккуоррі у тлумаченні, аналізі й трансформації бультманівської практики "деміфологізації" Нового Заповіту у своїй фундаментальній праці “Принципи християнської теології” (1966) спирається на шість чинників: досвід, одкровення, Св. Писання, традиції, культуру, розум. Вони фрормують фундамент його вчення про Бога, яке б "перетворилось на посередника поміж істинною християнською вірою та сучасним концептуальним полем раціонального мислення" (с. 125).

Репрезентовані в даній книзі думки англіканського теолога та філософра є, вочевидь, актуальними і для всього християнства, адже застерігають "від абсолютизації Біблії як 
головного і єдиного чинника богослів'я, який фрормує сенс людського буття”. Адже “... переконання, що Біблія є непогрішимою ... вмирає в деяких частинах християнського світу. ..., Біблія не є самими одкровенням. Християнське одкровення виявляється в людині, а не в книзі". Тому, ..., критичне вивчення Біблії, і визнання того, що і інші чинники є вагомими в богослів'ї, зрештою додає більшої вірогідності біблійному вченню і не суперечить раціоналістичним доктринам" (с. 128).

На нашу думку, концептуально монографія Г. Ємельяненко, К. Райди, С. Шевченка, з одного боку, провокує й можливість виникнення теоретичної дискусії з приводу співвідношення та протиставлення цінностей в постмодерністському та постекзистенціалістському мисленні, а з іншого, необхідність та доцільність перевидання даної праці у доповненому вигляді, за рахунок розгляду проблеми цінностей в екзистенціальній соціології, екзистенціальній антропології, екзистенціальній педагогіці, екзистенціальній політології тощо.

Тому і немає сумнівів у тому, що вказане авторським колективом проблемне коло питань відповідним чином відтворює одну з маловідомих й недосліджених площин сучасного світоглядного мислення, і у цьому сенсі їхню монографію можна загалом оцінити у якості позитивного та вагомого внеску не лише в вітчизняний історико-філософський дискурс, а й світову гуманітаристику загалом.

\section{() Ірина Василівна Васильєва}

